\title{
1. Parody
}

What is parody? Historically, the term has been applied to a wide variety of literary genres, from the shortest of prose pieces through to monumental novels, from prose to poetry, to styles of writing traditionally seen as standing in diametrical opposition to one another. It has been neglected and even condemned by influential writers and critics, from Goethe to F. R. Leavis, as a trivial form of literature, reflecting a more general and an ancient prejudice against comedy as a valid mode of thought or expression, or a worthy object of criticism. ${ }^{1}$ The existence of a tradition of negative assessment of the worth of parody necessitates to some extent its defence as well as its definition if it is to be used successfully as a critical term. As a critical term, parody has also been used with a great deal of imprecision, and has often been confused with pastiche, contrafact, cento and travesty. Given the sheer range of parodic literature, as well as the similarities between it and the other textual strategies it is often confused with, it is perhaps unsurprising that a favoured solution to the problem of delineating parody from other related forms has been to define it in a number of reductive ways, as imitation of form with changes to content, as ridicule through inappropriate contrast of high and low subjects, as a general mode of writing, as a purely literary, intertextual form, and as satiric criticism of ideologies. This study will argue that these are all parodic possibilities. However, placement of such theoretical emphasis on one aspect of parody at the expense of all others encourages a schematic, classificatory understanding of literature

W.K. Wimsatt: "The Criticism of Comedy" in: Hateful Contraries. Studies in Literature and Criticism. Kentucky, 1965, pp. 90-127. 
which artificially separates often overlapping forms of authorial practice, making theory less applicable to the understanding of literary texts, and producing theoretical definitions which make unnecessary claims of mutual exclusivity. ${ }^{2}$ Reductive definition has thus further abetted negative assessments of the worth of parody. A historical approach to the problem of the definition and reception of the term 'parody' can show how the term has changed in meaning over time, revealing recent and contemporary sources of its inadequacy as a critical term. Fortunately, and despite the many reductive definitions of parody offered by literary critics, authors have continued to produce complex works which necessitate a wider understanding of the concept of parody.

The English term 'parody' (German Parodie) has its etymological roots in a complex of Greek words, $\pi \alpha \rho \omega \delta 1 \alpha$, $\pi \alpha \rho \alpha \delta \circ \sigma$ and $\pi \alpha \rho \omega \delta \varepsilon$, parodia, parados and parode respectively. The etymology of the word suggests the possibility of basing a definition of parody on interpretations of extant uses of the term parodia in ancient Greek literature, such as Aristotle's use of the term in the Poetics, Athenaeus' use of the term in The Deipnosophists, and the use of the term by the Aristophanic scholiasts. ${ }^{3}$ Used in its earliest extant form by Aristotle, with reference to the comic transformation of heroic epics, it would seem that the term parodia gradually acquired new meanings, so that the Aristophanic scholiasts were able to

2 The contradictory but equally problematic definitions of parody offered by Grellman and Liede in successive editions of the Reallexikon der deutschen Literaturgeschichte (1926/28 and 1966) are cited as examples of this problem. See also: Theodor Verweyen and Gunther Witting: Die Parodie in der neueren deutschen Literatur: eine systematische Einführung. Darmstadt: Wissenschaftliche Buchgesellschaft 1979, pp. 69-75.

3

Rose: "Ways of defining parody" in: Parody: Ancient, Modern, and Post-Modern, pp. 5-53. The view of parody to be advanced in this study is most heavily indebted to the work of Margaret Rose. 
use it, in the context of parody of tragedy, to refer to "all sorts of comic literary quotation and allusion". ${ }^{4}$ These comic literary quotations and allusions ranged from the appropriation of particular plots and characters through to the use of dramatic conventions such as that of the tragic chorus. Certainly, the existence of semantic ambiguity in the prefix 'para', that is, its ability to denote imitation, parallel relationship and opposition, ${ }^{5}$ lends weight to the suggestion that the term was used to designate a complex variety of comic forms and intentions in antiquity. ${ }^{6}$ Conversely, ancient uses of the terms parados and parode seem to have misled some later commentators to limit the meanings and potential uses of parody as a critical term, since the use of these terms was confined more to the designation of imitation, particularly in music, where parados refers to the practice of singing in imitation, while parode refers to the imitation of a specific song, or 'ode'. ${ }^{7}$ Information about ancient uses and definition of parody therefore suggests the propriety of attempts at reviving pluralistic interpretations and uses of the term, without necessarily attempting to arrive at a definition based entirely on the uses and meanings of the ancient term, an attempt which would probably prove to be futile due to lack of extant textual evidence.

Common to all ancient Greek definitions of parody seems to

${ }^{4}$ Rose: Parody: Ancient, Modern, and Post-Modern, p. 15.

${ }^{5}$ Verweyen and Witting: Die Parodie in der neueren deutschen Literatur, p.

4. Winfried Freund: Die literarische Parodie. Sammlung Metzler, 200. Stuttgart: Metzler 1981, p. 1. In German, 'parody' transliterates intoParodie, and is translatable as Nebengesang, Beigesang or Gegengesang.

6 Rose: "Ways of defining parody".

${ }^{7}$ Rose: Parody: Ancient, Modern, and Post-Modern, pp. 7-8. 
be the requirement of a literary antecedent or model, and an acknowledgment of the comic, contrasting effect produced through the use of this antecedent; hence associations with comic discrepancy and laughter. However, the emphasis placed on these commonalities in influential interpretations of the ancient term indirectly paved the way for later, reductive definitions of both ancient and modern parody. Writing in the first century A.D., Quintilian (Marcus Fabius Quintilianus) insisted on the musical origins of the term parode in his Institutio Oratoria, and reported that some commentators had been led to insist on imitation as the defining aspect of literary parody "by an abuse of language". ${ }^{8}$ Confusion by later commentators between the terms parode and parodia frequently led to the application of Quintilian's definition of the former term to the latter. Quintilian also described parody as being pejorative in intent. ${ }^{9}$ J. C. Scaliger described ancient parody as comic inversion of a serious antecedent in his Poetices Libri Septem of 1561, which, combined with his use of the Latin ridiculus, led some later German and English commentators to link parody with absurdity and mockery, and hence to define it as a subspecies of travesty or burlesque. ${ }^{10}$ Moreover, later insistence on imitation as a defining aspect of parody, derived from the Renaissance concept of imitatio, and insistence on the existence of concepts of inversion and absurdity in definitions of the ancient term parodia, derived from Post-Renaissance critical uses of the term, produced dicho-

${ }^{8}$ Rose: Parody: Ancient, Modern, and Post-Modern, p. 8. Verweyen and Witting: Die Parodie in der neueren deutschen Literatur, pp. 5-7. Freund: Die literarische Parodie, p. 1.

9 Linda Hutcheon: A Theory of Parody: The Teachings of Twentieth Century Art Forms. New York, London: Methuen 1985, p. 50.

Rose: Parody: Ancient, Modern, and Post-Modern, pp. 9-10. Verweyen and Witting: Die Parodie in der neueren deutschen Literatur, p. 6. 
tomous typologies of parody which obscured earlier meanings and uses of parodia. Although Quintilian's and Scaliger's definitions were by no means solely responsible for later definitions, their reception, especially in the eighteenth century, together with contemporary changes in the meaning and use of the term, encouraged interpretative trends towards a narrowed understanding of the functions and importance of parody, and towards a separation, in modern literary and dictionary definitions of parody, of the serious from the comic, the high from the low, and of form from content.

From the eighteenth century, when the term Parodie entered the German language, well into the twentieth century, application of these dichotomies and attempts at avoiding them have characterised discussion and use of the ancient term parodia and the more modern term 'parody'. C. F. Flögel produced a typology of parody involving combinations of serious antecedent and comic adaptation, comic antecedent and serious adaptation, and so on. Other critics such as J. G. Sulzer and Johann Joachim Eschenburg attempted to distinguish between serious and comic types of parody, with the intention of defending parodic criticism whilst devaluing comedy. ${ }^{11}$ Such diverse concepts as rational utility, creative individualism, and the absolute existence and independence of an aesthetic realm further encouraged a negative 'assessment of parodic literature, and especially of parodic texts which seemingly lacked an openly critical or didactic function. Critics such as Gottsched poured scorn upon the form as part of a general devaluing of comedy, while Goethe delivered an influential negative assessment of contemporary parody. ${ }^{12}$

11 Freund: Die literarische Parodie, pp. 2-3.

12 In: "Über die Parodie bei den Alten" (1824), quoted by Freund: Die 
Concomitant with the reductive definition of parody was its confusion and conflation in the eighteenth century with the terms 'burlesque' and 'travesty'. As Margaret Rose has demonstrated, not only are burlesque and travesty terms of more recent origin than parody, but their meanings are further inextricably linked with notions of ridicule and inversion in ways which do not do justice to all the meanings of the more ancient term. ${ }^{13}$ Burlesque derives from the Italian burla, meaning 'a trick or joke', while travesty is traceable to the Latin travestire, meaning 'to disguise, to cloak'. Burlesque is usually described as a technique of inappropriate contrast, often by invoking distinctions between high and low subjects.

Although Grillparzer defended the critical aspect of some comic parody, ${ }^{14}$ and Friedrich Schlegel described Romantic irony as self-parody, ${ }^{15}$ reductive definitions of parody which emphasise imitation are reflected in much of the popular literary production of parody in the nineteenth century. Hundreds of almanacs of imitative parodies, travesties and contrafacts which appropriated and ridiculed popular literary antecedents were published, ${ }^{16}$ further encouraging the critical denigration of parody as a genre, and the critical neglect of its possibilities as an interpretative strategy or complex form.

Authorial practice has however preserved pluralistic uses of parody which recall ancient meanings of the term parodia through their complexity and variety. As recent research into early medieval German uses of parody has shown, the form

literarische Parodie, p. 3.

13 Rose: "Distinguishing parody from related forms" in: Parody: Ancient, Modern, and Post-Modern, pp. 54-100.

${ }^{14}$ Freund: Die literarische Parodie, p. 4.

${ }^{15}$ Rose: Parody: Ancient, Modern, and Post-Modern, p. 88.

${ }^{16}$ Freund: Die literarische Parodie, p. 6 
was considered to be as elementary an aspect of Literaturfehde as criticism itself, operating on the basis of both the conventions of literary genres and the style of particular authors, that is, on both form and content. ${ }^{17}$ Against the prevailing literary conventions of the Humanist period, where imitation of authoritative texts was preferred to criticism, Grimmelshausen included comic criticism and 'refunctioning' of styles, themes and genres in his novel Simplicius Simplicissimus. ${ }^{18}$ In terms of authorial practice it is possible to construct a canon of similar large scale novels contemporaneous with the reductive definition of parody, which defy most reductive definitions of parody whilst subsuming many of them as possibilities. Their defining parodic features are the appropriation of preformed text, and metafictional acknowledgment or highlighting of this appropriation, simultaneously emphasising the fictional nature of the narrative and criticising or relativising the preformed material. This canon would include Miguel de Cervantes' Don Quixote, Lawrence Sterne's Tristram Shandy, James Joyce's Ulysses, Thomas Mann's Doktor Faustus, Alfred Döblin's Berlin Alexanderplatz and Günter Grass' Die Rättin, among others.

It is the prominence of imitative forms of shorter parody during the nineteenth century, and the existence of a tradition of complex novelistic parody which leads Linda Hutcheon to downplay the significance of shorter forms of parody more generally:

\footnotetext{
17 Theodor Verweyen and Gunther Witting: "Parodie, Kontrafaktur" in: Walther Killy and Volker Meid (ed.): Literatur Lexikon: Begriffe, Realien, Methoden. Gütersloh, München: Bertelsmann 1993, pp. 193196, p. 195. 18

Verweyen and Witting: "Parodie, Kontrafaktur", p. 195.
} 
[...] in contrast to those short, occasional parodies that were gathered into anthologies with such regularity in the late nineteenth and early twentieth centuries, the kind of parody upon which I wish to focus is an integrated structural modelling process of revision, replaying, inverting and "trans-contextualising" previous works of art. $^{19}$

Hutcheon's contrasting of short, occasional parody with "the practices of novelists like Joyce and Mann"20 seems however to equate length with complexity. The view advanced in this study is that even apparently direct parody of a single text can generate incredibly complex meanings, in the light of awareness of the possible functions of parody, and familiarity with a parodied text and its interpretative history.

The persistence of emphasis on reductive features of parody as defining aspects is revealed in recent dictionary definitions of parody as "ridiculing imitation", ${ }^{21}$ and suggests the unprofitability of recourse to such definitions. The definition of parody offered by the Oxford English Dictionary, for example, combines misunderstanding of the ancient term with a modern definition associating parody with ridicule, implicitly separating high and low and even confusing parody, burlesque and thereby travesty:

parody: [ult. ad. Gr. $\pi \alpha \rho \omega \delta 1 \alpha$ a burlesque poem or song, f. par(a-) beside, in subsidiary relation, mock-, etc. + ode, song, poem; perh. immed. from L. parodia or F.

${ }^{19}$ Hutcheon: A Theory of Parody, p. 11.

${ }^{20}$ Hutcheon: A Theory of Parody, p. 11.

21 Hutcheon: A Theory of Parody, p. 5. 
parodie (1622 in Hatz.-Darm.)]

1. A composition in prose or verse in which the characteristic turns of thought and phrase in an author or class of authors are imitated in such a way as to make them appear ridiculous, especially by applying them to ludicrously inappropriate subjects; an imitation of a work more or less closely modelled on the original, but so turned as to produce a ridiculous effect. Also applied to a burlesque of a musical work. ${ }^{22}$

Even in dictionaries of literary terms, parody is often defined as the opposite of travesty through application of the same form and content dichotomy, and as imitation:

Parodie (griech. = Gegengesang), ursprünglich in griechischer Musik die Verzerrung. In der Literatur die verspottende, verzerrende oder übertreibende Nachahmung eines schon vorhandenen ernstgemeinten Werkes (auch eines Stils, einer Gattung) oder einzelner Teile daraus unter Beibehaltung der äußeren Form (Stil und Struktur), doch mit anderem, nicht dazu passendem Inhalt - im Gegensatz zur Travestie; Form der kritischen, antithematischen Textverarbeitung. Beide Gattungen erreichen Komik durch die Diskrepanz zwischen Form und Inhalt und durch die nur vom Original aus verständlicher Abwandlung derselben. [...] ${ }^{23}$

Since such definitions are rarely applicable to actual parodies,

22

"parody" in: J. A. Simpson and S. C. Weiner (ed.): Oxford English Dictionary. 2nd edition. Oxford: Clarendon 1989, Volume XI, p. 247.

23 "Parodie" in Gero von Wilpert: Sachwörterbuch der Literatur. 7., verbesserte und erweitete Auflage. Stuttgart: Kröner 1987, p. 660-662. 
especially complex novels containing parody, critics have been forced to claim that some parodies contain elements of travesty and some travesties contain elements of parody, ${ }^{24}$ or to argue that complex use of preformed material is better described as satire. ${ }^{25}$

A two-fold approach to the problem of defining parody seems to be required. Since the terms parody, travesty, contrafact, cento and pastiche describe a variety of strategies which make use of similar techniques of textual appropriation, parody is best defined in relation to these strategies in order to restrict its meaning within this field. However, from the proposition that parody, travesty and contrafact are interpretative strategies, it follows that interpretative components must be involved in their definition and use as critical terms. This suggests that the presence of parody, travesty and contrafact must be recognised by the reader, and it will be argued that appropriate definitions can be arrived at by positing the existence of a number of elements which allow for the balancing of formal, structural properties of texts with their possible semantic and rhetorical functions. Since parody is claimed to be a strategy which appropriates and interprets preformed material, it also follows that familiarity with the preformed material and its status as literature would be advantageous in illuminating possible relationships between the preformed material and its use in a new context, and thus in the reception of a text as parody rather than as travesty or contrafact. In the light of these claims, this study will argue that parody can perform complex semantic and rhetorical functions, and is therefore

${ }^{24}$ Alfred Liede: "Parodie" in: Reallexikon der deutschen Literaturgeschich 25 te. W. Kohlschmidt and W. Mohr (ed.), Berlin and New York 1966, p. 13.

This view of parody is advanced by George A. Test in: Satire: Spirit and Art. Tampa: University of Florida Press 1991. 
better understood in terms of interpretative responses to specific texts than solely as a genre or set of stylistic features. This approach to the definition and use of parody as a critical term not only subsumes many of the techniques or features previously claimed to be definitive aspects of the form; it is intended that the interpretative components of the definitions of parody, travesty, contrafact, cento and pastiche produced using this approach will be able to help clarify some problems of genre, intention and reception with respect to recent responses to Grimms' version of 'Rotkäppchen' ( $K H M$ 26). It will be shown that despite the apparent simplicity of the preformed material to be examined, application of a wide variety of textual strategies in its appropriation has created parodic texts which can be read in a number of complex ways. Accordingly, five elements of the aesthetic of perceiving textual strategies which involve the appropriation of a literary antecedent are proposed, intertextual, metafictional, comic, critical and creative. Each of these elements has descriptive or classificatory, and explanatory or interpretative components, which combine to suggest signals for the presence of diverse textual strategies including parody, travesty, contrafact, pastiche and cento, and reader prerequisites for the recognition and reception of these strategies. The central facet of parody will be shown to be its 'double-coded' nature, and it will be argued that the ambivalence inherent in the relationship between the appropriation of preformed material and its reception within a new context makes possible multiple readings of parodic texts. In the explanations which follow, these elements will be described as 'elements of parody', since it is argued that all five of these elements must be present in combination in a text, in order to signal the presence of parody to the reader. ${ }^{26}$ 
A limited concept of intertextuality is useful in defining parody and other related strategies. Intertextuality is understood in this study in its simplest form, as reference to a text from within the frame of another text. Intertextuality which makes use of preformed material involves two interpretative processes, where the first is the appropriation and incorporation of preformed material into a new text by the author, and the second is the recognition of the existence of preformed material in the new text by the reader. For a text to be perceived by the reader as making use of some strategy which involves the appropriation of preformed material, s/he must therefore be able to recognise the presence of two or more 'codes' within a text. ${ }^{27}$. The relationship set up between the 'code' of the preformed material and the 'code' of its new context is however ambivalent, since appropriated preformed material is received simultaneously as a part of the structure of the new text, and independently of the new text in relation to its source. Recognition of the presence of two codes can thus set up a relationship of opposition between the two codes, or the codes can operate in tandem to formulate other messages or allow for other possibilities of interpretation. This ambivalent intertextuality is an element of parody. Since the preformed material involved may range from words or phrases through to characters, events and structuring devices such as third-person narrative, intertextuality as defined here can proceed from form or content, or a mixture of the two. Inter-

26

See: Chapters 4-4.5 of this study, and especially Chapter 4.1, 'The Little Girl and the Wolf', for model interpretations which adopt this approach to parody.

27 This view of parody as dependent on reader reception, and the use of five elements which signal the presence of parody, is adopted from Margaret Rose, who proposes this model in: Parody: Ancient, Modern, and Postmodern. 
textuality as it pertains to parody and other related strategies is therefore neither synonymous with quotation, which declares the introduced text to be foreign through the use of stylistic conventions such as inverted commas and footnotes, nor can it be understood as an expansive term constructed to exhaust the interpretative possibilities of the new text, because the reader can understand intertextual reference in the context of a wider ambivalent relationship between codes, rather than merely within a closed system of antecedent and imitation.

The double-coded nature of the textual appropriation involved in this process is highlighted or 'foregrounded' by the expectations of the reader with respect to the preformed material, and possibly by reference from within the frame of the text to the fact of appropriation. Reference to the fictionality of a text from within the fictional frame is known as metafiction, and has the effect of evoking the expectations of a reader from within the frame of the text, by referring to the constructed nature of the narrative. Metafiction can thus be said to call the epistemological situation of reading into question, that is, the convention of reading a text for meaning and its associated reader expectations. Since metafictional devices also tend to highlight the discontinuous, heterogeneous nature of what is being read, metafiction can be described as an element of parody.

The setting up of a comic relationship between preformed material and its new context is another possibility resulting from the appropriation of preformed material. Comic effects are often described as being produced through contrast, discrepancy, incongruity or unfulfilled expectation. ${ }^{28}$ In parodic

28

See for example: Rainer Warning: "Elemente einer Pragmasemiotik der Komödie" in: Wolfgang Preisendanz and Rainer Warning (ed.): Das Komische. München: Fink 1976, pp. 279-333. 
texts, comic effects combine with intertextuality to signal a process of "controlled discrepancy" ${ }^{29}$ by which pre-existing material is incorporated into a new text, setting up a relationship between the literary antecedent and the new text, and hence between the codes present in the new text itself. The fact that this discrepancy can be 'controlled' through the presence of comic effects to suggest a range of possible relationships between the literary antecedent and the new text, and hence the possibility that the preformed material may gain a new range of functions if the text is read as employing parody, also suggests that comic effects are an element of parody.

The perception of a comic discrepancy between preformed material and its new context relies on the evocation of reader expectations. If the reader associates a particular set of expectations with the source of the preformed material, and these expectations are disappointed, or fulfilled in an unexpected manner, then the reader may also come to understand the new text as being critical of the preformed material or its source. Criticism in the new text is thus produced by the reader's reception of the other elements of parody in combination, and can be said to be an interpretative component of parody. Understanding of the critical element of parody is also greatly enhanced by a familiarity with the source of appropriated material, and in the case of a text, by knowledge of its social existence as literature, where familiarity with appropriated material consists of knowledge of its formal, structural, stylistic and generic properties, and the social existence of a text as literature consists of an appropriated text's Wirkungsgeschich$t e$; that is, its history of interpretation, and the concomitant social and didactic uses to which it has been put. It also follows 29

Rose: Parody: Ancient, Modern, and Post-Modern, p. 32. 
from this that the classification of any given text as parody, travesty, contrafact, cento or pastiche must be made with respect to a literary antecedent, and that this is only possible when interpretative parameters have been delinated for that literary antecedent. ${ }^{30}$

The creative component of parody results from its ability to 'refunction' preformed material, that is, from the new range of functions and interpretative possibilities which emerge from interactions between the intertextual, metafictional, comic and critical elements of parody, and the reader's reception of these elements. This suggests that there are many potential signals for the presence of parody. ${ }^{31}$ Since parody often signals its appropriation of preformed material, knowledge of the parodied text is not necessary for the reader to recognise the presence of two or more codes (although if the reader does know the parodied text s/he will be better able to compare the parodied text with any given parodic text). Furthermore, the reader can come to know a parodied text through the parodic text, and to understand the discrepancy between the preformed material and its new context entirely through the new text.

If these five elements, intertextual, metafictional, comic, critical and creative, are all present within a text, then the reader can understand the techniques which produce them as signals for the presence of parody. The absence of one or more of the elements suggested above produces other related forms such as travesty, contrafact, cento and pastiche. Alternatively, failure on the part of the reader to recognise one or more of the

30

Concomitant emphasis on the reception history of parodied texts, and thus on the social existence of literature, is suggested by Theodor Verweyen in: Eine Theorie der Parodie: Am Beispiel Peter Rühmkorfs. München: Fink 1973, pp. 55-78.

${ }^{31}$ Rose: Parody: Ancient, Modern, and Post-Modern, pp. 37-38. 
above elements can lead him/her to read a parodic text as travesty or contrafact, or independently of the appropriation of preformed material, as a creative work. Furthermore, a conscious decision on the part of the reader not to consider select aspects of one or more of the above elements permits $\mathrm{him} / \mathrm{her}$ to read a parodic text in any one of these ways.

Thus, in order to describe parody as an interpretative textual strategy and to distinguish this definition from reductive definitions based on a single technique of textual appropriation, the critical term 'parody' is defined as follows:

A textual strategy which seeks to signal the appropriation of preformed material in a comic, metafictional manner, and creatively 'refunction' it, achieving a critical distance from which comment on the source of the preformed material and its social existence can be made.

This definition has three main features; it proposes that a wide variety of signals can suggest the presence of parody to the reader, that the reader must receive these signals in combination in order to be able to interpret a parodic text as such, and posits a familiarity on the part of the reader with the source of the preformed material, in order to understand the critical element of parody. It also subsumes the reductive form and content, inversion and absurdity, antecedent and imitation definitions as possible aspects of parody (and indeed of other strategies), claiming for parody the unique ability to be critical, comic and creative in its use of preformed material. The textually referential particularity of parody's intertextual aspect combines with its other co-existing defining elements to suggest that it is capable of fulfilling a range of interpretative, 
text-historical and didactic functions. It also follows from the claim that the preformed material is creatively imbued with a new range of functions and interpretative possibilities that some of these functions will operate independently of the source of the preformed material, that is, that the parodic text has an independent aesthetic existence.

The terms travesty and contrafact are proposed as descriptions of less ambivalent yet distinctly interpretative textual strategies. Contrafact describes a strategy where stylistic, formal or structural elements of a genre are used to formulate a message which is independent of the source of the preformed material, and may not necessarily be exploited for comic purposes, that is, where the text cannot be said to adopt a critical stance towards the source of preformed material. This strategy is common in political speeches and in advertising slogans and campaigns. Many Kunstmärchen also fit this description. In contrast, travesty describes a strategy where preformed material is appropriated for the specific purpose of creating a comic discrepancy. A typical technique which produces travesty is the substitution of an inappropriate or incongruous Textsorte (type of text), as in the case of a Märchen rewritten using mathematical formulae. In the case of travesty however, the possible ways in which the text can be read with respect to the preformed material are exhausted by the comic element of appropriation. $^{32}$

The common interpretative component linking travesty and contrafact is that the text cannot be read as taking a critical stance towards the preformed material. In both cases, the 'target' of the textual strategy is outside of the text and its social existence. Generally, travesty exploits a literary ante-

${ }^{32}$ See: Chapter 4 , pp. 87-89 for examples of travesty and contrafact with respect to 'Rotkäppchen' ( $K H M$ 26). 
cedent for its comic potential, while contrafact exploits a literary antecedent for its communicative potential, suggesting that travesty is a special type of contrafact. However, the suggestion that travesty and contrafact exploit a literary antecedent for the specific purpose of criticising an extra-literary subject raises the possibility that they may be essentially satiric forms.

Critical discussion of parody and satire operates, of necessity, at a murky confluence between literary generalisation and historical, textually referential particularity. Parody, as "the comic refunctioning of preformed linguistic or artistic material", ${ }^{33}$ as "repetition with critical distance" ${ }^{34}$ is rooted in textually referential particularity, yet ambivalent in its message due to its dependence on such material, in short, due to its double-coded nature. The fact that parody produces a range of possible interpretations could also be taken as signalling the presence of irony. On the other hand, satire, as "an attack by means of a manifest fiction upon discernible historical particulars" ${ }^{35}$ appears directed in its message, yet its requirement of manifest fictionality makes it self-referential, producing ambivalence. Satiric ambivalence may also serve to emphasise an ironic discrepancy between the historical particulars being attacked and the suitability or relevance of the means being used to attack them, or between different levels of representation, as in the contrast between reality and an ideal. Ambivalence and irony would seem to be common factors which link parody and satire. Certainly, all three terms, parody, satire and irony, have some points of mutual contact. ${ }^{36}$ But it is

Rose: Parody: Ancient, Modern, and Post-Modern, p. 52.

35 Hutcheon: A Theory of Parody, p. 18.

This definition of satire is taken from Edward J. Rosenheim: Swift and the Satirist's Art. Chicago: University of Chicago Press 1963. 
meaningless to point out that parody sometimes has a satiric purpose, and that satirists often use parody as a device, the question becoming one of means and ends.

It is however possible to distinguish between satire and some parodic texts. Although parody does not necessarily ridicule the referent text, it does incorporate it, often in order to criticise or relativise it. Its reception as such thus depends on the reader's recognition of the presence of two 'codes', and the discrepancy involved. This double-coding produces comic contrast, and can therefore be contrasted with irony, which functions without the necessary requirement of two 'codes' to create a discrepancy. Irony can therefore be described as being produced when a single 'code' can be interpreted in more than one way, revealing its relationship to satiric ambivalence. For this reason, it has been claimed that irony is generally more cryptic than parody. ${ }^{37}$ Although parody can be said to be critical of preformed material, its structural dependence on this preformed material means that the overall attitude to the preformed material is itself ambivalent, a complex of criticism and sympathy, of attitudes which "combine to creatively expand the possibilities of the parodied text." ${ }^{38}$ Parody therefore tends to emphasise the literary nature of discourse (whilst not denying the possibility of extraliterary functions). Parody, through its ambivalence and double-coded nature, also lends itself to 'ludism' or gameplaying, which tends to relativise possible interpretations of the parodic-text. Satire, on the other hand, is "extramural in its

36

Hutcheon: A Theory of Parody, p. 55.

Rose argues for this view of parody and irony. See: Parody: Ancient, Modern, and Post-Modern, p.88.

38

Rose: Parody: Ancient, Modern, and Post-Modern, p. 51. 
aim", 39 and since it does not necessarily have an intertextual component, it can be said to be less dependent on the subject or material it criticises. As Margaret Rose points out, "the object of the satirist's attack remains distinct from the satirist and generally plays a comparatively minimal role in adding to the structure or aesthetic reception of the satirist's work". 40

Because of the predominance of extramural components, travesty and contrafact can hence be described as forms of satire. Some parody can also be considered to be satiric in intent, as a special type of satire where means and ends unite, so that preformed material and the historical particulars associated with it are attacked by means of a manifest fiction (which takes the form of textual appropriation and the metafictional signalling of this appropriation). ${ }^{41}$ But not all parody can be said to be unambiguously satiric, and it is still possible to read satiric parody in ways which do not emphasise its critical component.

Like the terms parody, travesty and contrafact, the terms cento and pastiche also describe textual strategies which appropriate preformed material, but unlike these terms, cento and pastiche describe strategies which are not appreciably interpretative, and are hence more or less 'value-free'. Cento generally consists of the stringing together of quotations from a literary work or a variety of literary works in order to achieve a comic effect, and is thus essentially an imitative strategy. Pastiche

39 40

Hutcheon: A Theory of Parody, p. 43.

Rose: Parody: Ancient, Modern, and Post-Modern, p. 89.

${ }^{41}$ George Test: Satire: Spirit and Art. Test considers terms such as parody and travesty to be 'useless' as critical terms; although some of their uses may be subordinate to satire, Test's claim about their 'uselessness' is problematic, since the terms he replaces them with such as 'irony of violated content' relate to formal, structural and stylistic properties rather than semantic and rhetorical functions. 
describes a similar strategy, but does not produce a discernible comic effect, so that the appropriation of preformed material may not even be obvious to the reader. Since these strategies lack a discernible interpretative or critical component, they are taken to be of limited interest in the context of this study. This method of defining parody suggests that parody is the main term of the family, since a text which employs parody can be understood in the greatest variety of ways, even if the reader does not recognise all of the relevant signals. On the other hand, it also takes issue with the source of the preformed material in the most direct manner, by signalling the appropriation of preformed material through metafictional comment, and by adopting a critical perspective on the preformed material itself. It is thus possible, thanks to the ambivalent, double-coded nature of the parodic text, for it to criticise or relativise preformed material whilst simultaneously constructing an independent message. This understanding of parody echoes Theodor Verweyen's concept of totale Parodie, where the parodic text directs its message against the sense, style and structure of the source of the preformed material, bringing about a correspondence of means with ends. Verweyen distinguishes between this type of parody and instrumentale Parodie, where preformed material provides a medium for criticism or satire of something else. ${ }^{42}$ Travesty, contrafact, cento and pastiche can be described both as instrumentale Parodie and hence as 'subordinate terms' with respect to the elements of parody described in this study, since they involve the exploitation of techniques also utilised in parody, but exploit these techniques either for their communicative potential, or in order to achieve a comic effect. Parodic texts are unique, in 42

Freund: Die literarische Parodie, p. 15. 
that they can be read either as comment on the preformed material, or in terms of an independent message. Furthermore, parodic texts can be read without the reader necessarily having to perceive or understand all of the signals for parody. A parodic text can be read purely in terms of its comic nature, as criticism, as some mixture of the two, or even without the recognition of comic discrepancy or criticism, since the text still conveys some message independent of parodic elements. This also suggests the difficulty of defining parody as "kritische, antithematische Textbearbeitung", ${ }^{43}$ since it is argued that this is only one possible way of reading a parodic text.

The five elements proposed above define a family of textual strategies in which 'preformed linguistic or artistic material' is appropriated. In its widest sense, appropriation of the past is usually described as influence. An Intentionalist concept of influence sees the artist or author as a solitary genius (Goethe's Originalgenie), who creates by the force of his or her artistic genius. This Promethean view of a God-like artist or author has been opposed in more recent literary theory by a negative conception of influence. Harold Bloom has advanced the concept of an 'anxiety of influence', where the production of art and literature consists of an Oedipal struggle to break free from the tyranny of influence. ${ }^{44}$ This negative conception of influence is however still linked with the Promethean ideal through the metaphor of struggle, and the suggestion that the artist or author must play the role of a single, coherent Originalgenie to succeed. According to this understanding of art, the signalling of textual appropriation by any means other than conventional stylistic techniques such as inverted commas

43

Gero von Wilpert: "Parodie".

44 Harold Bloom: The Anxiety of Influence: A Theory of Poetry. Oxford, New York: Oxford University Press 1973. 
and footnotes is inappropriate; textual strategies which incorporate preformed material into their own structure are seen as parasitic whether they signal textual appropriation or not, and, to use another of Bloom's terms, the authors who produce them are considered to be 'weak poets'.

However, another viewpoint from which to consider strategies of textual appropriation follows from considering the artist or author to be a rational critical intelligence, a viewpoint implicit in the use of the word 'strategy' to suggest agency. From this viewpoint, textual appropriation involves two authorial practices, critical reading of the preformed material followed by the production of text, producing, in Bloom's terms, 'strong readings' of a literary antecedent by incorporating its material in order to refunction it, or to create a comic or inappropriate contrast. The preformed material is simultaneously highlighted and refunctioned through this creative process, producing a mixture of criticism and comedy. However, this process can only be recognised through familiarity with the appropriated material and its social existence as literature, a familiarity which is also necessary in order for the reader to recognise the presence of parody, and distinguish parody from travesty, contrafact, cento and pastiche.

Although this study makes the claim that parody is an interpretative strategy, it cannot be inferred from this that it is possible to know the intentions of an author through text. While it may seem reasonable to claim that it is possible to make educated guesses about author intention in the light of reliable biographical and historical information, highlighted textual appropriation and metafictional comment on the fact of this appropriation tend to 'foreground' the problem of intentionality, since they emphasise the fictional, discontinuous 
nature of what is being read by highlighting the presence of two or more 'codes', and hence the fact of the multiple authorship of any parodic text. Attention is thus drawn to the process of reading itself. Drawing attention to the process of reading however emphasises the role of rational critical intelligence on the part of the reader. The convention of reading a text for meaning encourages the reader to take a special kind of 'interest' in the literary text which in turn encourages him/her to make connections between the social existence of the text and its relationship to other texts, or even to reflect upon the epistemological situation of reading. ${ }^{45}$

This approach stresses the ambivalent nature of parody. It can be seen that it is inappropriate to describe parody as a device which ridicules an antecedent, since a parodic text incorporates preformed material into its own structure in order to criticise it and formulate its own message. Parody can thus be said to be dependent on preformed material in a way in which travesty is not, since the preformed material is not a target of travesty, but is rather used in order to criticise something else through inappropriate contrast or comic incongruity. Contrafact is dependent on preformed material for the formulation of its own message, but does not criticise this preformed material. Furthermore, it can be seen that none of these three strategies need necessarily exploit dichotomous typologies of form and content, serious and comic, or high and low. Parody, as a strategy which relies on foregrounding of the heterogeneity of text, and on preserving the interpretative possibilities of a text

This concept of 'interest' is advanced by Steven Knapp in opposition to theories which utilise, for example, Platonic or Kantian metaphysics to confer a 'literary' status on a text independent of its interpretation. See: Steven Knapp: Literary Interest: the Limits of Anti-Formalism. Cambridge, Massachusetts: Harvard University Press 1993. 
through co-existence of intertextual, metafictional, comic, critical and creative elements, is in fact in a unique position, in that its use can actually call the application of such dichotomies in the interpretation of a literary text into question. Parody could therefore be seen to be the strategy most 'interpretative' of preformed material, followed by contrafact, travesty, cento and pastiche. Pekoral is a special case which appears as a result of consideration of textual strategies in the above terms. It designates the perceived failure of a textual strategy in the light of familiarity with a parodied text and its history, while its application to a text would suggest that the author is a 'poetaster'.

In order to support this final contention about the interpretative potential of parody, and to test the validity and applicability of the definitions put forward in this study, it will be necessary to examine texts which can be said to utilise these textual strategies. Jacob and Wilhelm Grimms' version of 'Rotkäppchen' (KHM 26) is proposed as a source of preformed material, since it is a text which has been subjected to a wide variety of interpretations, and used for diverse purposes, literary and extra-literary. Furthermore, preformed material has been appropriated from this text using a number of textual strategies and techniques of appropriation. Examination of texts which appropriate preformed material from this text is therefore intended to demonstrate the interpretative potential of various textual strategies, and the inability of reductive definitions of parody, especially those based on form and content, to explain their use of diverse techniques of textual appropriation. Furthermore, by delineating some interpretative parameters for the appropriated material, it will be possible to examine the functions of preformed material in several sample 
parodic texts, and hence to suggest ways in which the preformed material can be said to have been refunctioned. Accordingly, in order to consider parody as an interpretative response to Grimms' version of 'Rotkäppchen' and to decide whether such parody reflects more generally on the $K H M$ in which 'Rotkäppchen' (KHM 26) was first published, it will first be necessary to examine the parodied text's status as literature, and the status of the versions of the KHM in which it is to be found: 